\title{
NEOLIBERALISM(S) AS A GUIDE TO POST-WALL URBAN CHANGE: \\ EXPLANATION OUT OF THE BLUE?
}

\author{
Michael Gentile and Örjan Sjöberg ${ }^{1}$
}

Article forthcoming in Tijdschrift voor Economische en Sociale Geografie (accepted version).

\begin{abstract}
Concerns have been raised that neoliberalism has become the favoured, yet uncritically applied lens used to approach and explain societal developments. This contribution assesses research on an area where this concern has been pronounced, namely the formerly centrally planned economies of Europe. Examining a sample of more than 200 articles published in twelve geography, area and urban studies journals over the period 2000-2014, findings suggest that while neoliberalism is not generally used as a blanket explanation for patterns of change following the collapse of the Berlin Wall, it is occasionally gratuitously afforded explanatory power. Moreover, in this role it is rarely defined and more rarely still validated empirically. Thus, in about one tenth of the sampled literature, the importance of neoliberalism is asserted rather than shown.
\end{abstract}

Keywords: neoliberalism; theory; empirical validation; urban studies; Central and Eastern Europe

\section{INTRODUCTION}

Recent research into the significance of neoliberalism as a major force in urban management has increasingly come to focus on its real or imagined impact (Le Galès 2016; Pinson \& Morel Journel 2016, 2017; Storper 2016; Birch 2017). Following on the heels of observations by scholars who suggest that from a 'non-Western' perspective neoliberalism as a prime driver of urban change is of limited relevance (e.g., Ong 2011; Robinson 2011; Parnell \& Robinson 2012; Baptista 2013; Tang 2014; Ouředníček 2016; Buckingham 2017), such critique mirrors concerns raised that the status of neoliberalism "as the explanatory term for contemporary forms of economic

\footnotetext{
${ }^{1}$ Corresponding author: orjan.sjoberg@hhs.se.
} 
restructuring" risks "obscur[ing] the details and complexity of the processes involved" (Larner 2003, p. 509; emphasis in the original). Indeed, there has been a widespread fear that a concept that "seems to be everywhere" (Peck and Tickell 2002, p. 380), and that "defies explanation in terms of fixed coordinates" (Peck 2010, p. 20), has often simply been assumed to explain the emergence of entrepreneurial urban governance.

An early observation to this effect is the argument that, in European urban studies, there is a need of "balancing the peculiarities of place with an understanding of the generalizability of the processes observed by the researcher" (Latham 2006a, p. 88; also Cochrane 2006). This, however, is difficult as "Anglo-American urban studies is increasingly organized around a tight consensus about the main trends shaping the contemporary city" (Latham, 2006b, p. 377). It is a problem, Latham (2006b, p. 377) continues, as "the structure of concerns which this consensus organizes means that work on the European city is often not well equipped to observe and understand the many interesting and hopeful things which fall outside the terms of the consensus."

As scholars have increasingly gone about investigating whether specific urban policies are in fact neoliberal in character, the other issue alluded to - that of neoliberalism being used as a blanket explanation - has not received much empirical attention. Although the prospects of neoliberalism becoming a taken for granted explanation was discussed already two decades ago, there are few, if any, studies that systematically try to assess that claim. While this might be because the crisis in 2008 granted "the explanatory status of neoliberalism" (Peck 2013, p. 132) a new lease of life, we do not know the extent to which researchers simply assume that neoliberalism is the explanans of the explanandum of urban development.

For a start, does neoliberalism tower above other interpretations and does it have a position of self-evident importance? To the extent that it does, is it validated by some means or is its role as the favoured explanation taken for granted? Conclusive answers are probably not attainable, but these questions are nevertheless ultimately empirical and at least partly verifiable.

Therefore, this paper addresses these questions by exploring whether neoliberalism is seen as an important, or even dominant, explanation in recent research within "post-Wall" urban studies. The choice of this particular field stems from our perception that neoliberalism has gained particular prominence within urban studies generally, and our familiarity with Central and Eastern Europe (CEE) enables us to suggest that a multitude of neoliberal manifestations could be identified across the region. CEE represents a setting in which neoliberal policies can be investigated, but where the importance of such policies and related expressions has not been conclusively confirmed or rejected. Given that the empirical support (as opposed to summary 
statements) for the idea that neoliberalism is "at the heart of any explanatory system" (Pinson \& Morel Journel 2016, p. 139) has not been awarded much attention in the urban studies literature as a whole, our contribution here is intended to be of interest beyond geography and the confines of the European transition economies.

Our approach is descriptive because we need to grasp the extent of the problem, yet it is not feasible to cover the entire relevant literature. With this limitation in mind our paper starts from the observation that neoliberalism is used frequently in discussions on 'post-socialist' urban development. After verifying this assertion, we discuss how its application as a theoretically useful concept has been justified (if at all), and whether it has been used with an explanatory purpose (and if so, how).

As some prominent research on CEE urbanism does take the issue of the nature and particular mechanisms of neoliberalism seriously (e.g. Stenning et al. 2010; Collier 2011; Golubchikov et al. 2014), we expect to find a certain measure of sophistication throughout much of this literature. At the very least, this should be true of work appearing during the past decade or so and some recent work (e.g. Kalyukin et al. 2015; Büdenbender \& Zupan 2017) certainly indicates that the substantive message has been received.

Our contribution is organised as follows. We start in the next section by presenting our data. We then move on, in the third section, to how neoliberalism is employed in research on urban developments in CEE and in the former Soviet Union (FSU). Our findings indicate that a substantial part does not demonstrate that neoliberalism, as an empirical phenomenon, has had a major impact on the region. The overarching conclusion is that this impact may have been present, but it cannot be established based on the surveyed works because the analysis of neoliberalism itself tends to be superficial: the importance of neoliberalism is often invoked rather than shown.

\section{THE EMPIRICS OF POST-WALL URBAN SCHOLARSHIP}

Keeping in mind the importance of establishing the nature of neoliberalism to be able to assess its presence and effect, we now explore the conceptual landscapes of post-Wall change. We need to establish whether references to neoliberalism are plentiful or not, and whether any connection as might be suggested is established empirically or at least made probable using logic and theory.

Also as we limit ourselves to but a part of the urban studies literature, it is easy to see that a survey of the extant literature in its entirety is impractical. Hence an appropriate sampling method is necessary. We define urban studies broadly to include both intra- and inter-urban phenomena, 
but we exclude specialised studies that favour phenomena that are not necessarily urban in nature (such as housing, migration or transportation) and are not explicitly set in an urban studies context. Accordingly, we survey a dozen English-language journals publishing papers on urban developments in CEE/FSU, albeit with varying intensity or perhaps degree of enthusiasm. This selection represents the international literature, and it is here that we are likely to find studies with the greatest exposure and impact. It is also where we are most likely to find expressions of the tension at the heart of the exchange between Latham (2006a, 2006b) and Cochrane (2006).

By only selecting journals published outside the region, we may be criticized for perpetuating the inequitable Western hegemonic order (Timár 2004). As shown by Borén and Young (2016), nothing prevents us from including journals from the geographical area in focus. Our rationale is that the articles appearing in non-area journals have to compete for editors' attention and space with other articles, be they urban studies contributions with a different geographical focus or studies within entirely different sub-fields of geography. Similarly, multidisciplinary area studies journals imply competition with non-urban studies material. All this indicates that there will be less scope for purely descriptive papers to be included in our sample and, if still descriptive, they can be presumed to be thought of as of interest for wider audiences.

We selected five general (human) geography journals (Annals of the Association of American Geographers; Environment and Planning A; Geografiska Annaler: Series B, Human Geography, Tijdschrift voor Economische en Sociale Geografie; Transactions of the Institute of British Geographers), four urban studies journals (Cities, International Journal of Urban and Regional Research, Urban Geography, Urban Studies), and two area studies journals (Eurasian Geography and Economics, Europe-Asia Studies). We also include a journal that targets a specific geographical domain (but one that extends beyond CEE/FSU) that doubles as a field journal primarily focused on urban and regional change (European Urban and Regional Studies). Several of the journals are natural outlets for geographers, others see intensive publication by representatives of other disciplines (predominantly sociologists and urban planners, but also political scientists, anthropologists, architects, architectural historians, historians and economists).

Because the term neoliberalism or its derivatives in social science journals only takes off at some point from the mid- to late 1990s (Peck 2010, p. 13), we limit our selection to articles published between 2000 and 2014. This allows us to include papers that may have been exposed to the notion of neoliberalism, thereby enabling their authors to assess the value and utility of the concept. By not taking it fully up to date (i.e. 2015-2018), on the other hand, we avoid including articles that might shy away from the notion of neoliberalism because of the critique it has become subject to over the past few years. ${ }^{3}$ 
Setting such bounds has consequences. As in an earlier review of the literature (Kubeš 2013), non-English language publications are under-represented (indeed, there are none in our sample), while monographs or articles in edited collections are not considered at all, meaning that also much existing work in English falls outside of the scope of our study. As a result, we are not able to generalise beyond what has been observed in our sample, and our survey, which will only be reported as summary descriptive statistics, should be interpreted accordingly.

Although we spend some effort identifying use of theory as such, in the analysis of the individual articles references to neoliberal policies take pride of place; we are particularly interested in cases where neoliberalism is explicitly chosen or avoided in face of alternatives. We want to know how, and towards what end(s), the concept is used, if at all. Our simple and non-exhaustive classification includes instances ranging from mere mentioning to its use as an analytical category. The latter may or may not include explicit definitions or conceptualisations of neoliberalism. Here it is important to include any discussion on the relevance of "actually existing neoliberalism" (Brenner \& Theodore 2002), "variegated neoliberalism" (Peck \& Theodore 2010) or neoliberalisation as a process or evolving concern (Peck \& Tickell 2002; Castree 2006) as captured for instance by "variegated neoliberalization" (Brenner et al. 2010). After all, considerations that build on "a process-based understanding of neoliberalism, as an evolutionary pattern of regulatory restructuring" (Peck 2010, p. 276) have become an integral part of the literature on neoliberalism. Also when a particular work recognises neoliberalism's lack of definitional stability (Peck 2013, p. 133; Dunn 2017, p. 451) or notes that it leaves ample space for additional theorising (Bernt 2009, p. 756) the notions of "roll-back" and "roll-out" type of policies (Peck \& Tickell 2002) can be employed to distinguish between different actions that might fit under the general label of neoliberalism. As such, it would infuse the concept with a measure of analytical capacity. (However, it does not necessarily remove the risk of turning the notion of neoliberalism into something that fails to meet the criterion of being testable.)

\section{FINDINGS}

The sample - 209 articles meet our sampling criteria, for an average of 17.4 per journal or little more than one article per journal and year (Table 1). Variation across journals is considerable in part reflecting differences in the overall number of articles published in an average year. Beyond this, the tally differs along several dimensions. Over time, the number of articles on post-1989 urban change has increased, doubling between the first and the third five-year period. Again, we find noticeable differences across journals, reflecting not only variation in the overall number of 
articles but also the inclusion of relevant special issues. Urban Studies and Environment and Planning $A$, both of which are high-volume outlets, differ in their coverage of urban CEE/FSU, presumably because one is an urban studies journal, and the other a general human geography (and increasingly general social science) one. Because of their wider substantive and geographical scope, general journals publish relatively less on any given subject than do field or area studies journals. Moreover, there may also be an inverse effect in that a narrower scope makes it easier to reach the relevant audience, inducing authors to send their work to field journals rather than to general ones, no matter the status of the latter.

In neither case can we draw any inferences on the relative success of submitted papers; that would require confidential data on the number of submitted manuscripts. Even so, as also noted by Borén and Young (2016, p. 593), it appears that some journals are more open to papers on and from the CEE/FSU region than are others. Similarly, Bajerski and Przygoński (2018) show that the presence of authors affiliated with research environments within the region in focus here differs quite substantially across our sample. This might be because of geographical or epistemological proximity, the journal's mission, or a more or less sympathetic stance of the editor(s) and reviewers. At the most basic level, it may simply reflect the competition for space and editor attention.

Because of the limitations of our sample, an analysis of the articles' geographical scope only offers a partial illustration of the places that are on and off the map of post-Wall urban scholarship. The sample is sufficiently large and representative however to allow us to sketch some broad tendencies.

[Table 1]

While some papers in the sample - nine altogether - are of a general character, many others limit themselves to the cities or urban systems of particular countries. The general papers include seven works on post-1989 urban developments, and one each on socialist and Soviet cities, respectively. In addition, we find six papers on (East) Germany, four on the Czech Republic, three on Poland and Estonia, two on Kazakhstan and Hungary, one on the Balkans, the Soviet Union, Ukraine, Uzbekistan, Russia, Croatia and Slovenia, and one on Tomsk oblast' of Russia. However, the largest share of our sample relies on (usually single) case studies of particular cities (Figure 1). The major cities of Central Europe, as well as Moscow, St Petersburg and Tallinn, dominate the literature, whereas some countries are entirely absent. Moreover, Russia and, especially, Ukraine are heavily under-represented in view of these countries' demographic weight. 
[Figure 1]

The most frequently studied city is Berlin (31 articles), which has a prominent position not only in the post-socialist city literature, but also in influential discourses and debates outside of this forum. With less than half the number of articles, the next group of cities includes Moscow and St Petersburg (15 each), Budapest (13) and Tallinn (13). The next four are all major capitals (Warsaw 11; Sofia 9; Bucharest and Prague 8), after which the second-tier cities make their appearance. Overall, most papers concern large cities with more than half a million inhabitants, while smaller ones only appear sporadically. The smallest towns included in the sample are Koper/Capodistria in Slovenia, followed by Zyryanovsk and Leninogorsk (Ridder) in Kazakhstan. The sample's most over-represented city, in relation to its population size, is Tallinn, while three of the region's ten most populous are completely absent (Tashkent, Minsk and Kharkiv); the largest outside Russia and third overall, Kiev, appeared for the first time only in 2014.

Theory, or the lack thereof - Geography in particular, but also other social science research conducted in the region (e.g. Kürti and Skalník 2009), suffer from a lingering reputation for being descriptive rather than driven by theory. This apparent reluctance to engage with theory - other than at most "importing" it for local use - makes it harder for urban scholars focusing on CEE/FSU to reach out to wider audiences (Sjöberg 2014). Although empirical work decidedly can add up to new insights and novel theoretical constructs (Ouředníček \& Pospíšilová 2016, p. 793), research that keeps theory at an exaggeratedly respectful distance may also appear less innovative. In short, descriptive work and single case studies are not an effective strategy to win the attention of hard-nosed editors from outside the region.

[Table 2]

If so, all of this might interfere with any ambition to publish in well-known journals. Our first task therefore is to establish whether theory in general plays a role in the work culled from our chosen source journals. It does: 55 per cent of the sampled articles engage with theory (Table 2).

Application of theory ${ }^{4}$ here refers to a measure of substantive engagement, meaning that theory is explicitly either tested or applied (i.e., as part of an analytical framework, such as deriving 
concepts or research questions). Strictly conceptual papers also qualify into this category. There are several ambiguous cases where theoretically permeated concepts take pride of place without much being made of their links to explicitly identified theory (urban vulnerability, institutional thickness, politics of scale are some examples found in our sample). In yet others, we find research that engages with theory, but only in a shallow or derivative way. In such cases, authors are given the benefit of the doubt and are included in the theory column in Table 2. On the other hand, not being included in this category does not necessarily mean being out of touch with the wider world of scholarship. Most articles in our sample include literature surveys, and while the contribution is not always made explicit, authors do tap into ongoing scholarly conversations. Such work may of course inform inductively derived theory and models at a later stage, but this is impossible to tell until it happens.

A first observation is that the most visible general journals in our sample, the Annals of the $A A G$ and Transactions of the IBG, clearly are demanding: all published articles engage with theory. Environment and Planning $A$ is something of an exception here though, but in all three numbers are small and therefore susceptible to chance events. The other two society journals, the aims and scope of both of which explicitly demand theoretical connectivity (Geografiska Annaler: Series B, Human Geography, Tijdschrift voor Economische en Sociale Geografie), fall somewhere in-between. It seems clear, though, that at least the former of the two has a strong preference for theoretically informed work. Turning to the urban studies journals, theory is obviously not a precondition for publication. Whether that is because purely descriptive work is explicitly welcomed (as in the City profile section of Cities) or because these articles bring something else to the table (method, for instance, or commentaries on previously published work) cannot easily be established. Overall, papers that are informed by theory have an edge, if not necessarily a very pronounced one. The area studies journals, finally, also present a mixed picture, but then largely because one of them, Eurasian Geography and Economics, for the period under review here had an explicit policy of favouring insights into current developments. ${ }^{5}$

Perhaps of lesser consequence is the observation that also amongst those articles that explicitly make use of a theory few discuss alternatives. While it is certainly true that there may be few options - and perhaps the contribution is all about introducing theory in the first place - it is noticeable that there are so few instances where the pros and cons of potentially competing theories are subject of deliberation. To allow proper assessment (i.e., the choice can be made subject to scrutiny by readers), such arguments in favour of some theory or model at the expense of another ought to be presented on grounds of logic or on grounds of the perceived inappropriateness of existing formulations (e.g. the assumptions of a particular theory may not be applicable in the 
examined setting). In the set of articles surveyed here, cases include Cséfalvay (2011) who settles for a public choice approach to gated communities and Wiest (2012) who turns to postcolonial theory for an alternative to the modernisation paradigm. Along similar lines, Valiyev (2014) notes the limited progress made in applying some "imported" theories (pluralist and public choice) to the region, and instead proposes the use of another notion, Molotch's (1976) growth machine.

Empirical constraints may hold back plans to bring competing theories or hypotheses to the data (in our sample Kabisch et al. 2010, on re-urbanisation and gentrification is a case in point). Yet, even allowing for such obstacles, our sample of $200+$ articles contains few cases where competing positions derived from the literature are put to test with a view to discriminate between explanations. One is Marcińczak et al. (2012), where urban social polarisation à la Sassen (1991) and Wilson (1987) are set against each other. Another is Kovács and Hegedűs (2014), partly following in the footsteps of Cséfalvay (2011), who draw on a rich repertoire of theory, identifying two basic and typically mutually exclusive processes related to "gating" - market and politics driven processes, respectively - with the latter prevailing.

If we were to move on to those cases where authors do not try to pitch one construct against another, but simply derive hypotheses from the literature in order to test them, the numbers would increase perceptively, but largely (yet not exclusively, e.g. Rosol 2010) thanks to articles employing analytical quantitative approaches. More common still are those instances where existing theories and models are used to organise the material at hand. A representative example is Marcińczak and Sagan (2012), who use traditional urban ecology models to classify data arranged by spatial planning units, with validation using discriminant analysis. Naturally, such use of prior constructs is not limited to quantitative work but is also found among those who favour qualitative approaches, for instance Kotus (2013), who draws on Arnstein's (1969) ladder of citizen participation.

All of this suggests that theory matters. Its use may take many forms: providing a source of inputs (e.g. concepts or observations) to an analytical framework or for deriving research questions; propositions to be tested, either in the sense of holding up to empirical scrutiny or also being applicable in the (post-)socialist realms; something that can be built upon (including instances where theory or models are modified or extended) with application in mind; and finally a source of alternative approaches and potential explanations. The latter is relatively rare, as the penultimate column in Table 2 attests.

The issue of explanation, however, is more complicated than the mere reference to theory. In order to explain something we need to think about how causality may be established. Strategies include using multivariate techniques (if only in a probabilistic sense), tracing processes or chains 
of events implying causes and effects, and approaches based on logic (including the explicit identification of necessary and sufficient conditions). In the process, theory is a guide, but it cannot always be taken at face value (is it applicable? has it been thoroughly tried and tested? etc.) and therefore often remains an entry point for provisional propositions.

As a minimum, to use theory we would require information on what needs to be explained, how the theory could be expected to do that and under what conditions it can be done. The latter includes the assumptions that should be met, but also the domain(s) to which the theory might apply. Indeed, to qualify as a scientific theory, it should not only be logically consistent but also in principle be testable directly or by generating testable implications. Thus, it is not a requirement that we can test it here and now - data might be missing or appropriate methods of analysis may not be available - yet ultimately it should be possible to subject the theory to tests based on empirics, logic or both. In most of our sampled articles, authors have been careful not to extend their theory based claims beyond the pale, yet as Latham (2006b) points out there is always a risk that blanket explanations are imposed and then typically at the expense of context. Globalisation and neoliberalism are the two examples mentioned (cp. Larner 2003) and we now turn to the latter to see how it has been used. Certainly, neoliberalism, as a vehicle for description or as an explanatory factor, is relevant to the study of cities in CEE and the FSU. Our question is rather what role the concept has assumed, if any, in the literature.

Enter neoliberalism - From the above it appears that some version of middle-range theory à la Merton (1957), that is a process of theorising where theory and empirics go hand in hand, is the preferred approach of urban studies scholars taking an interest in the region. This transcends the traditional home of such theorising, sociology, and is used by the majority irrespective of disciplinary background. Neoliberalism, as an intellectual construct, does not quite fit that mould.

The point is neither that it is normative as opposed to positive - it certainly can but does not have to be thought of in such terms - nor that we have to confine it to the social structure that in Merton's world towers above or beyond middle-range theory. Rather it is that neoliberalism can be approached both as an empirical phenomenon and as theory, including a theory put into practice. Indeed, Harvey $(2005$, p. 21) cautions us "to pay careful attention, therefore, to the theory of neoliberalism and the actual pragmatics of neoliberalization." Flew (2014), for his part, identifies six different ways of conceptualising neoliberalism, not all of which are mutually compatible. These range from an "all-purpose denunciatory category" to a "variant within the broad framework of liberalism as both theory and policy discourse", via neoliberalism "as the things are", "as a policy 
doctrine" (particularly relevant to the English speaking world), "the dominant ideology of global capitalism" and "neoliberalism as hegemony". That final category comes in two forms, one issuing from Michel Foucault, the other from David Harvey.

Flew (2014) views neoliberalism in terms of historical institutionalism, with aspects of Foucault and Weber added for good measure. He labels all six conceptualisations theories, on our reading because the conceptualisations (rather than neoliberalism per se) aspire to explain what is essentially an empirical phenomenon. Even so, the denunciatory category sits uneasily with the notion of theory as an intellectual construct seeking to explain something that can tested and Flew (2014, p. 52) suggests that it will fail at least on the criterion of being falsifiable à la Popper. (A less charitable view would suggest that it is not verifiable either.) Some aspects of neoliberalism could well meet such criteria, but not all of them (value statements not being amenable to classification along the true-false spectrum) - and this would presuppose that statements or hypotheses on the nature of neoliberalism that contribute towards a negative stance are made explicit.

Against this background, the approach in the analysis of our sample is to look at the use of neoliberalism (or any of its derivative terms) as something that intends to explain one or more outcomes. We turn our attention away from instances where it is used solely for derogatory purposes (as opposed to being constructively critical), focusing instead on whether or not neoliberalism is defined or conceptualised so as to allow verification. This assessment targets the level of the individual article and includes both its use in general (no matter how fleetingly) and any claims, explicit or implicit, made with respect to the explanatory power of neoliberalism (however conceived). If the concept is imbued with such power, we then look for a verification of that capacity. If present, we take a closer look at how it is done, and if not, we consider whether neoliberalism is simply assumed to impact urban society or the phenomenon in focus, and/or on what grounds it is assumed to be relevant.This exercise is reported in Table 3.

\section{[Table 3]}

The result is that neoliberalism is frequently named, but perhaps not as frequently as expected. Clearly, it is not the obvious frame of reference. Neoliberalism is referred to in 28 per cent of the articles, often only in passing. As a check on the ubiquity of the term it fails dramatically, but we can nevertheless confirm its presence in studies on CEE/FSU urbanism. (Given that our sample also includes a fair number of articles referring to the socialist rather than following period, 
the percentage would be somewhat higher if that was taken into account.) Within this sub-sample, neoliberalism is defined in six.

That would have been no surprise, had it not been that a considerably larger number of articles claim that neoliberalism explains observed outcomes (it is four times larger: 29 in all or $13.9 \%$ of the full sample). Since only a minority of the six articles that provide some kind of definition actually verify its presence or significance, the number of papers that simply assume neoliberalism to be important is higher than might be expected considering the level of sophistication, care and circumspection that could and should be applied in dealing with core terms and constructs. As it happens, and because one of the six pieces is conceptual (Sýkora \& Bouzarovski 2012) and therefore not a self-evident candidate for engaging in empirical verification to start with, only one of the articles that define neoliberalism attempts to ascertain that it is relevant in the sense of being present (Rosol 2010). Otherwise, neoliberalism is taken for granted, or we are treated to assertions that it squares with experiences elsewhere. At best, it is a starting point that is not taken for granted (e.g. Bernt 2009, where the objective is to identify the local sources of variation in neoliberal policies).

We may speculate as to why this is the case. Taking the arguments of Latham (2006a) seriously, the general urban studies literature is one obvious potential such source. Another can be found in the literature on shift from socialism to post-socialism itself. For, as Sýkora and Bouzarovski (2012, p. 45) contend, “[t]he term 'transition' has mainly been associated with the neoliberal agenda of shock therapy, based on the radical replacement of the basic political and economic institutions of socialism with democratic and market arrangements". However, as Harvey (2005, p. 46) notes, "[t] he need to maintain fiscal discipline is a matter of concern in its own right and does not, like monetarism more generally, necessarily entail repressive redistribution" as typically associated with neoliberalism. The same could be said of high levels of inflation, rapidly increasing unemployment and other adverse effects of the early post-Wall period. Something had to be done about it, and it was not necessarily some coherent set of policies that could be labelled neoliberal that was on the top of the mind of policy makers (or even foreign consultants). It is only after a few years that the alternatives began to crystallise, and at that point the shock therapy part was typically quietly abandoned, as Swain (2011) has noted. This does not mean that neoliberalism would inevitably have to meet the same fate, but it should caution us not to draw a straight line from the economic calamities of 1989-1991 (or 1991-1993/94 in the case of FSU) to some coherent programme intent on establishing a neoliberal order. Again, to the extent that it did, it has to be demonstrated, rather than simply asserted or assumed. 
While we would like to emphasise that the great majority of the 59 articles that allude to neoliberalism do not explicitly equate shock therapy and neoliberalism, seven of them do (of which three claim that neoliberalism is the main explanatory factor). Also with respect to the introduction of neoliberal policy prescriptions the majority - 41 out of 59 - actively avoid reading neoliberalism retrospectively as the immediate response to the collapse of central planning. Yet, this also implies that almost a third do, providing a clue to how neoliberalism is often approached in this corner of urban studies, if it indeed enters the picture at all. Not only are many influenced by trends in the wider urban studies community, and perhaps a bit too keen to import interpretive frameworks that risk banishing local context to the margins as Latham (2006a) warns; equally important is that the somewhat loosely attached label of neoliberalism hints at it being taken for granted.

\section{CONCLUSION}

Although we are able to lay to rest the suspicion that neoliberalism has assumed the position of the default explanation in post-Wall urban studies, we can confirm that the concern expressed by Latham (2006a) cannot be disregarded. References to neoliberalism are frequent, but still only a minority of the articles surveyed uses that label, often in a critical and reflective manner. Even so, more than one article in eight bestows neoliberalism, however conceived, with explanatory power. That would not have been a problem had it not been the case that the great majority of that relatively small set of papers infuses neoliberalism with explanatory power without defining what neoliberalism is or what it is likely to entail (one out of ten articles in the full sample does so). As such it is an expression of the willingness to import ideas into ex-socialist urban studies (Sjöberg, 2014), but it also betrays an at times uncritical disposition that goes against the grain of important work in this area of research (including Stenning et al. 2010; Collier 2011; Kalyukin et al. 2015; Büdenbender \& Zupan 2017).

Is it, as Latham and others suggest (e.g. Pinson \& Morel Journel 2016; Storper 2016), the uncritical acceptance of Anglo-American urban theory and its emphasis on neoliberalism as the primary framework to explain urban change that has come to permeate urban studies elsewhere, well beyond the particular empirical setting where the "high theory" originates? If so, it resonates with the critique that postcolonial scholars and others have directed at the Los Angeles school of urban studies and similar high profile bodies of research (e.g. Ong, 2011; Parnell \& Robinson 2012; Tang 2014; Le Galès 2016). Or can its origin be found elsewhere, perhaps in the wider body of research on developments following the collapse of the centrally planned one-party state? That is, are references to neoliberalism as an explanation for empirically observed outcomes derivative of the debates on how to reform the formerly socialist countries? 
Indeed, some authors locate the introduction of neoliberalist precepts at the very beginning of the post-socialist period. However, this is not the only or even main position taken. Many recognise that the first steps away from socialism had little to do with neoliberal designs, its outward similarities notwithstanding. We do observe a measure of sophistication in the literature, which is able to distinguish between the contingencies of socialist collapse and the hurried measures taken in its wake, and the more orderly (if often politically contested or thwarted) plans to transform society once the worst problems related to the breakdown of the old system had been addressed. Any move away from that system will entail a move in the direction of some form of capitalism, be it the watered down capitalism of market socialism, or that of the robber barons, or anything in-between. It will therefore carry with it a semblance of conservative, liberal and indeed neoliberal preferences, but that does not necessarily indicate a neoliberal agenda.

It may still reflect ideas taken for granted at the time. But if so, it would presumably be more fruitful to think about it the way Dear $(1986,1994$; also Simon 2014) considered the ideas of postmodernism: as style, as method or as epoch. Just as the "grandest dimension of postmodernism is the last: its claim to represent an epochal transition" (Dear 1986, p. 373), also neoliberalism might be thought of as a particular period rather than as a coherent body of economic and political thought. Then, however, we leave the territory of Merton's (1957) mid-range theories and move into the realm of the master metaphor, that foundational thought upon which a paradigm might rest but that cannot be made subject to direct empirical test. In short, in parts of the relatively small but expanding universe of post-Wall urban studies, neoliberalism has been allowed uncritically to assume a position of self-evident importance, albeit one which might be eroded with time as evidence stacks up against it. As such, it remains as much a matter of faith as it is an empirical proposition. 


\section{References}

ARnsteIn, S.R. (1969), A Ladder of Citizen Participation. Journal of the American Institute of Planners 35(4), pp. 216-224.

BAjerski. A \& K. PRZygoński (2018), East-Central European Human Geographers in Englishdominated, Anglophone-based International Publishing Space. Geographia Polonica 91(3), pp. 265-280.

BAPTISTA, I. (2013), The Travels of Critiques of Neoliberalism: Urban Experiences for the "Borderlands". Urban Geography 34(5), pp. 590-611.

Bernt, M. (2009), Partnerships for Demolition: the Governance of Urban Renewal in East Germany's Shrinking Cities. International Journal of Urban and Regional Research 33(3), pp. 754 769.

BIRCH, K. (2017), A Research Agenda for Neoliberalism. Cheltenham: Elgar.

BorÉn, T. \& C. Young (2016) Conceptual Export and Theory Mobilities: Exploring the Reception and Development of the "Creative City Thesis" in the Post-socialist Urban Realm. Eurasian Geography and Economics 57(4-5), pp. 588-606.

Boudon, R. (1991), What Middle-range Theories Are. Contemporary Sociology 20(4), pp. 519-522.

Bouzarovski, S, S. Tirado Herrero, S. Petrova, J. Frankowski, R. Matoušek \& T. MaltBy (2017), Multiple Transformations: Theorizing Energy Vulnerability as a Sociospatial Phenomenon. Geografiska Annaler: Series B, Human Geography 99(1), pp. 20-41.

Brenner, N. \& N. Theodore (2002), Cities and the Geographies of "Actually Existing Neoliberalism". Antipode 34(3), pp. 349-379.

Brenner, N., J. Peck \& N. Theodore (2010), Variegated Neoliberalization: Geographies, Modalities, Pathways. Global Networks 10(2), pp. 182-222.

BuCKINGHAM, W. (2017), Uncorking the Neoliberal Bottle: Neoliberal Critique and Urban Change in China. Eurasian Geography and Economics 58(3), pp. 297-315.

BÜDEnbender, M. \& D. Zupan (2017), The Evolution of Neoliberal Urbanism in Moscow, 1992-2015. Antipode 49(2), pp. 294-313.

Castree, N (2006), From Neoliberalism to Neoliberalisation: Consolations, Confusions, and Necessary Illusions. Environment and Planning A 38(1), pp. 1-6.

ChelCEA, L. \& O. DruȚǍ (2016), Zombie Socialism and the Rise of Neoliberalism in Post-socialist Central and Eastern Europe. Eurasian Geography and Economics 57(4-5), pp. 521-544. 
Christophers, B. (2015), The Limits to Financialization. Dialogues in Human Geography 5(2), pp. 183-200.

Collier, S.J. (2011), Post-Soviet Social: Neoliberalism, Social Modernity, Biopolitics. Princeton, NJ: Princeton University Press.

Cochrane, A. (2006), (Anglo)phoning Home from Berlin: a Response to Alan Latham. European Urban and Regional Studies 13(4), pp. 371-376.

Cséfalvay, Z (2011), Gated Communities for Security or Prestige? A Public Choice Approach and the Case of Budapest. International Journal of Urban and Regional Research 35(4), pp. 735752.

DEAr, M. (1986), Postmodernism and Planning. Environment and Planning D: Society and Space 4(3), pp. 367-384.

DeAr, M. (1994), Postmodern Human Geography. Erdkunde 48(1), pp. 2-13.

Dunn, B. (2017), Against Neoliberalism as a Concept. Capital and Class 41(3), pp. 435-454.

FLEW, T. (2014), Six Theories of Neoliberalism. Thesis Eleven 122 (1), pp. 49-71.

French, S., A. Leyshon \& T. WAinwright (2011), Financializing Space, Spacing Financialization. Progress in Human Geography 35(6), pp. 798-819.

Gentile, M. (2018), Three Metals and the "Post-socialist" City: Reclaiming the Peripheries of Urban Knowledge. International Journal of Urban and Regional Research 42(6), pp. 1140-1151.

Golubchikov, O. (2016), The Urbanization of Transition: Ideology and the Urban Experience. Eurasian Geography and Economics 57(4-5), pp. 607-623.

Golubchikov, O., A. Badyina \& A. Makhrova (2014), The Hybrid Spatialities of Transition: Capitalism, Legacy and Uneven Urban Economic Restructuring. Urban Studies 51(4), pp. 617-633.

HaAse, A., D. Rink \& K. Grossmann (2016), Shrinking Cities in Post-socialist Europe: What Can We Learn from their Analysis for Theory Building Today? Geografiska Annaler: Series B, Human Geography 98(4), pp. 305-319.

HaRveY, D. (1989), From Managerialism to Entrepreneurialism: the Transformation in Urban Governance in Late Capitalism. Geografiska Annaler: Series B, Human Geography 71(1), pp. 317.

Harvey, D. (2005), A Brief History of Neoliberalism. Oxford: Oxford University Press. 
Ilchenko, M. \& D. Dushkova (2018), Editorial: In Search of the Post-socialist Urban Geography. How Do We See the Post-socialist City Today? Belgeo (4), pp. 1-6.

KABISCH, N., D. HAASE \& A. HAASE (2010), Evolving Reurbanisation? Spatio-temporal Dynamics as Exemplified by the East German City of Leipzig. Urban Studies 47 (5), pp. 967-990.

Kalyukin, A, T. Borén \& A. Byerley (2015), The Second Generation of Post-socialist Change: Gorky Park and Public Space in Moscow. Urban Geography 36(5), pp. 674-695.

Kotus, J. (2013), Position of the Polish City on the Ladder of Public Participation: Are We Going the Right Way? The Case of Poznań. Cities 35, pp. 226-236.

Kovács, Z. \& G. Hegedús (2014), Gated Communities as New Forms of Segregation in Postsocialist Budapest. Cities 36, pp. 200-209.

Kubeš, J. (2013), European Post-socialist Cities and Their Near Hinterland in Intra-urban Geography Literature. Bulletin of Geography Socio-Economic Series 19, pp. 19-43.

KÜRTI, L. \& P. SKALNÍK (2009), Introduction: Postsocialist Europe and the Anthropological Perspective from Home. In: L. KÜRTI \& P. SKALNíK, eds., Postsocialist Europe: Anthropological Perspectives from Home (pp. 1-28). New York: Berghahn.

LARNER, W. (2003), Neoliberalism? Environment and Planning D: Society and Space 21(5), pp. 509-512.

Latham, A. (2006a), Anglophone Urban Studies and the European City: Some Comments on Interpreting Berlin. European Urban and Regional Studies 13(1), pp. 88-92.

Latham, A. (2006b), Berlin and Everywhere Else: a Reply to Allan Cochrane. European Urban and Regional Studies 13(4), pp. 377-379.

LE GALÈS, P. (2016), Neoliberalism and Urban Change: Stretching a Good Idea Too Far? Territory, Politics, Governance 4(2), pp. 154-172.

MarcińCZaK, S. \& I. SAgan (2011), The Socio-spatial Restructuring of Łódź, Poland. Urban Studies 48(9), pp. 1789-1809.

MARCIŃCZAK S., S. MUSTERD \& M. STĘPNIAK (2012), Where the Grass is Greener: Social Segregation in Three Major Polish Cities at the Beginning of the 21st Century. European Urban and Regional Studies 19(4), pp. 383-403.

MERTON, R.K. (1957), Social Theory and Social Structure. Glencoe, IL: Free Press.

Molotch, H. (1976), The City as a Growth Machine: Toward a Political Economy of Place. American Journal of Sociology 82(2), pp. 309-332. 
MÜlLER M. (forthcoming), Goodbye, Postsocialism! Europe-Asia Studies DOI 10.1080/09668136.2019.1578337.

ONG, A. (2011), Introduction: Worlding Cities, or the Art of Being Global. In: A. RoY \& A. ONG, eds., Worlding Cities: Asian Experiments and the Art of Being Global (pp. 1-26). Oxford: WileyBlackwell.

OuŘEDNíčEK, M. (2016), The Relevance of “Western” Theoretical Concepts for Investigations of the Margins of Post-socialist Cities: the Case of Prague. Eurasian Geography and Economics 57(4-5), pp. 545-564.

OuŘEDníČEK, M. \& L. PospíšillovÁ (2016), Urban Dynamics and Neighbourhood Change in Cities after Transition. Sociologický časopis/Cz̨ech Sociological Review 52(6), pp. 787-794.

PARnELL, S. \& J. Robinson (2012), (Re)theorizing Cities from the Global South: Looking beyond Neoliberalism. Urban Geograpby 33(4), pp. 593-617.

PeCK, J. (2010), Constructions of Neoliberal Reason. Oxford: Oxford University Press.

PECK, J. (2013), Explaining (with) Neoliberalism. Territory, Politics, Governance 1(2), pp. 132-157.

PeCK, J. \& A. Tickell (2002), Neoliberalizing Space. Antipode 34(3), pp. 380-404.

Pinson, G. \& C. Morel Journel (2016), The Neoliberal City - Theory, Evidence, Debates. Territory, Politics, Governance 4(2), pp. 137-153.

Pinson, G. \& C. Morel Journel (2017), Introduction: Debating the Neoliberal City Thesis. In: G. Pinson \& C. Morel Journel, eds., Debating the Neoliberal City (pp. 1-38). Abingdon: Routledge.

RoBINSON, J. (2011), Cities in a World of Cities: the Comparative Gesture. International Journal of Urban and Regional Research 35(1), pp. 1-23.

Rosol, M. (2010), Public Participation in Post-Fordist Urban Green Space Governance: the Case of Community Gardens in Berlin. International Journal of Urban and Regional Research 34(3), pp. $548-563$.

Sassen, S. (1991), The Global City: New York, London, Tokyo. Princeton, NJ: Princeton University Press.

Schmiz, A. (2016), Staging a "Chinatown" in Berlin: the Role of City Branding in the Urban Governance of Ethnic Diversity. European Urban and Regional Studies 24(3), pp. 290-303.

Simon, D. (2014), Postmodernism and Development. In: V. Desai \& R.B. POTTER (eds), The Companion to Development Studies (pp. 142-146). London: Routledge. 
SJÖBERG, Ö. (2014), Cases onto Themselves? Theory and Research on Ex-socialist Urban Environments. Geografie 119(4), pp. 299-319.

Stenning, A., A. SMith, A. RochovskÁ \& D. ŚwIA̧TEK (2010), Domesticating Neo-Liberalism: Spaces of Economic Practice and Social Reproduction in Post-Socialist Cities. Oxford: Wiley-Blackwell.

Storper, M. (2016), The Neo-liberal City as Idea and Reality. Territory, Politics, Governance 4(2), pp. 241-263.

SwaIn, N. (2011), A Post-socialist Capitalism. Europe-Asia Studies 63(9), pp. 1671-1695.

SÝKORA, L. \& S. BouZArovski (2012), Multiple Transformations: Conceptualising the Postcommunist Urban Transition. Urban Studies 49(1), pp. 43-60.

TANG, W.S. (2014), Governing by the State: a Study of the Literature on Governing Chinese Megacities. In: P.O. BErg \& E. BJÖRner, eds., Branding Chinese Mega-Cities: Policies, Practices and Positioning (pp. 42-63). Cheltenham: Elgar.

TimÁr, J. (2004), More than “Anglo-American", it is "Western": Hegemony in Geography from a Hungarian Perspective. Geoforum 35(5), pp. 533-538.

VAliyev, A. (2014), The Post-Communist growth Machine: the Case of Baku, Azerbaijan. Cities 41(S1), pp. S45-S53.

Voiculescu, S. \& I.S. JuCU (2016), Producing Urban Industrial Derelict Places: the Case of the Solventul Petrochemical Plant in Timişoara. European Urban and Regional Studies 23(4), pp. $765-781$.

Wiest, K. (2012), Comparative Debates in Post-socialist Urban Studies. Urban Geography 33(6), pp. 829-849.

WiLson, W.J. (1987), The Truly Disadvantaged: The Inner City, the Underclass, and Public Policy. Chicago: University of Chicago Press. 
Table 1. The sample

\begin{tabular}{|c|c|c|c|c|}
\hline \multirow[t]{2}{*}{ Journal } & \multirow[t]{2}{*}{$\begin{array}{l}\text { number } \\
\text { of articles }\end{array}$} & \multicolumn{3}{|l|}{ by period } \\
\hline & & $2000-2004$ & 2005-2009 & 2010-2014 \\
\hline Annals of the Association of American & & & & \\
\hline Geographers & 5 & 2 & 0 & 3 \\
\hline Cities & 42 & 4 & 10 & 28 \\
\hline Eurasian Geography and Economics & 19 & 14 & 2 & 3 \\
\hline Environment and Planning $A$ & 6 & 0 & 2 & 4 \\
\hline Europe-Asia Studies & 10 & 2 & 5 & 3 \\
\hline European Urban and Regional Studies & 18 & 10 & 6 & 2 \\
\hline $\begin{array}{l}\text { Geografiska Annaler: Series B, Human } \\
\text { Geography }\end{array}$ & 12 & 1 & 8 & 3 \\
\hline $\begin{array}{l}\text { International Journal of Urban and Regi } \\
\text { Research }\end{array}$ & 24 & 3 & 4 & 17 \\
\hline $\begin{array}{l}\text { Tijdschrift voor Economische en Sociale } \\
\text { Geografie }\end{array}$ & 11 & 3 & 5 & 3 \\
\hline $\begin{array}{l}\text { Transactions of the Institute of British } \\
\text { Geographers }\end{array}$ & 5 & 1 & 2 & 2 \\
\hline Urban Geography & 19 & 4 & 5 & 10 \\
\hline Urban Studies & 38 & 5 & 11 & 22 \\
\hline Total & 209 & 49 & 60 & 100 \\
\hline
\end{tabular}


Table 2. Use of theory in sampled articles

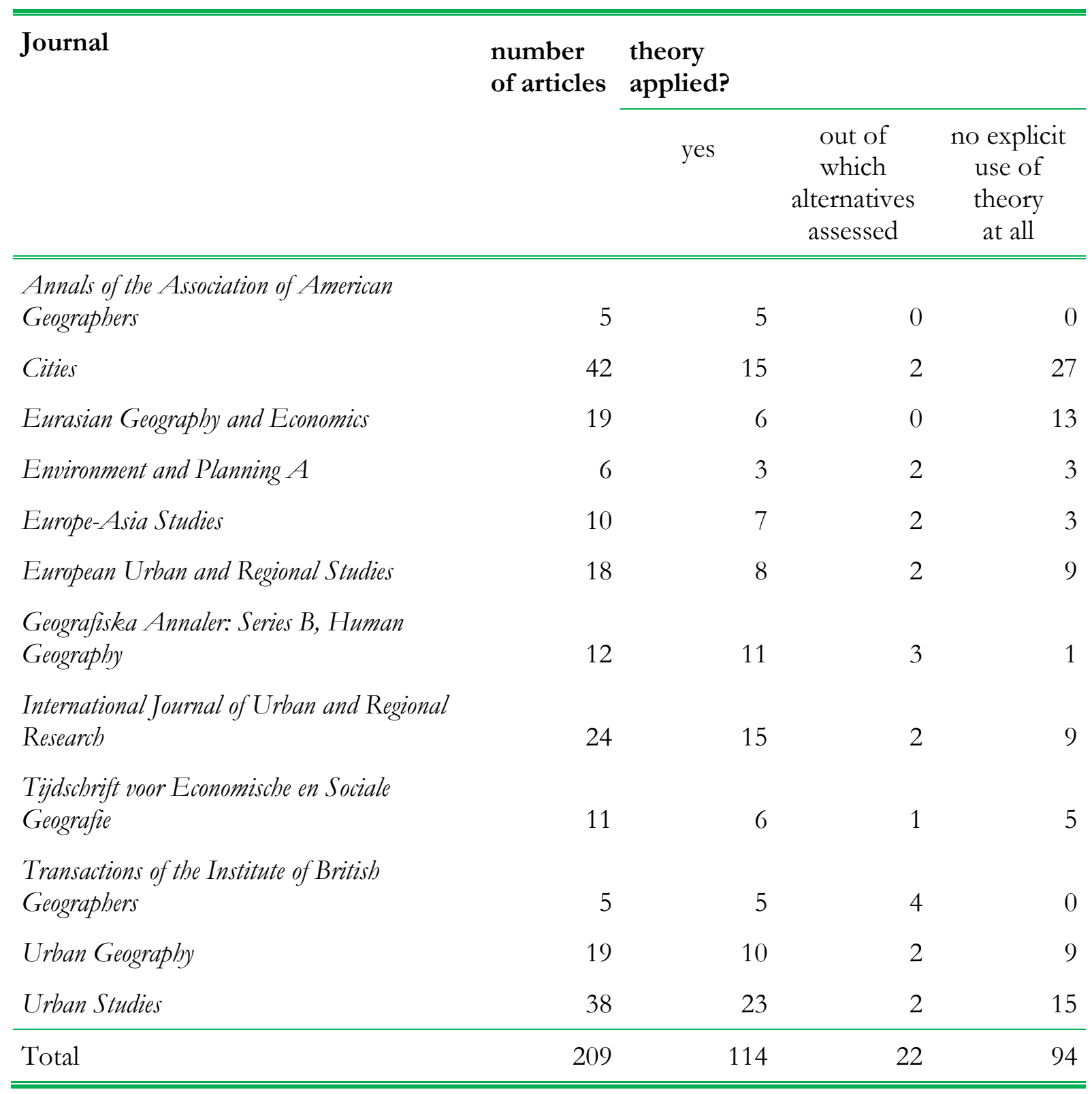


Table 3. The use of neoliberalism (and cognate variants) as an explanatory factor

Journal

articles in which neoliberalism is:

\begin{tabular}{llrr}
\hline & & $\begin{array}{r}\text { explicitly } \\
\text { verified by } \\
\text { own test }\end{array}$ & $\begin{array}{r}\text { used for } \\
\text { explanatory } \\
\text { purposes }\end{array}$ \\
mentioned defined & & \\
\hline
\end{tabular}

Annals of the Association of American

Geographers

$\begin{array}{rrrrr}1 & 4 & 0 & 0 & 0 \\ 8 & 34 & 0 & 0 & 7 \\ 1 & 18 & 0 & 0 & 0 \\ 3 & 3 & 0 & 0 & 2 \\ 2 & 8 & 1 & 0 & 1 \\ 7 & 11 & 1 & 0 & 1 \\ 2 & 10 & 1 & 0 & 1 \\ 13 & 11 & 2 & 1 & \end{array}$

International Journal of Urban and Regional

Research

Tijdschrift voor Economische en Sociale

\begin{tabular}{lrrrrr} 
Geografie & 3 & 8 & 0 & 0 & 2 \\
Transactions of the Institute of British & 4 & 1 & 0 & 0 & 2 \\
Geographers & 3 & 16 & 0 & 0 & 0 \\
Urban Geography & 12 & 26 & 1 & 0 & 8 \\
Urban Studies & 59 & 150 & 6 & 1 & 29 \\
\hline Total & & & & & \\
\hline \hline
\end{tabular}




\section{Caption}

Figure 1. Geographical focus of sampled articles by city

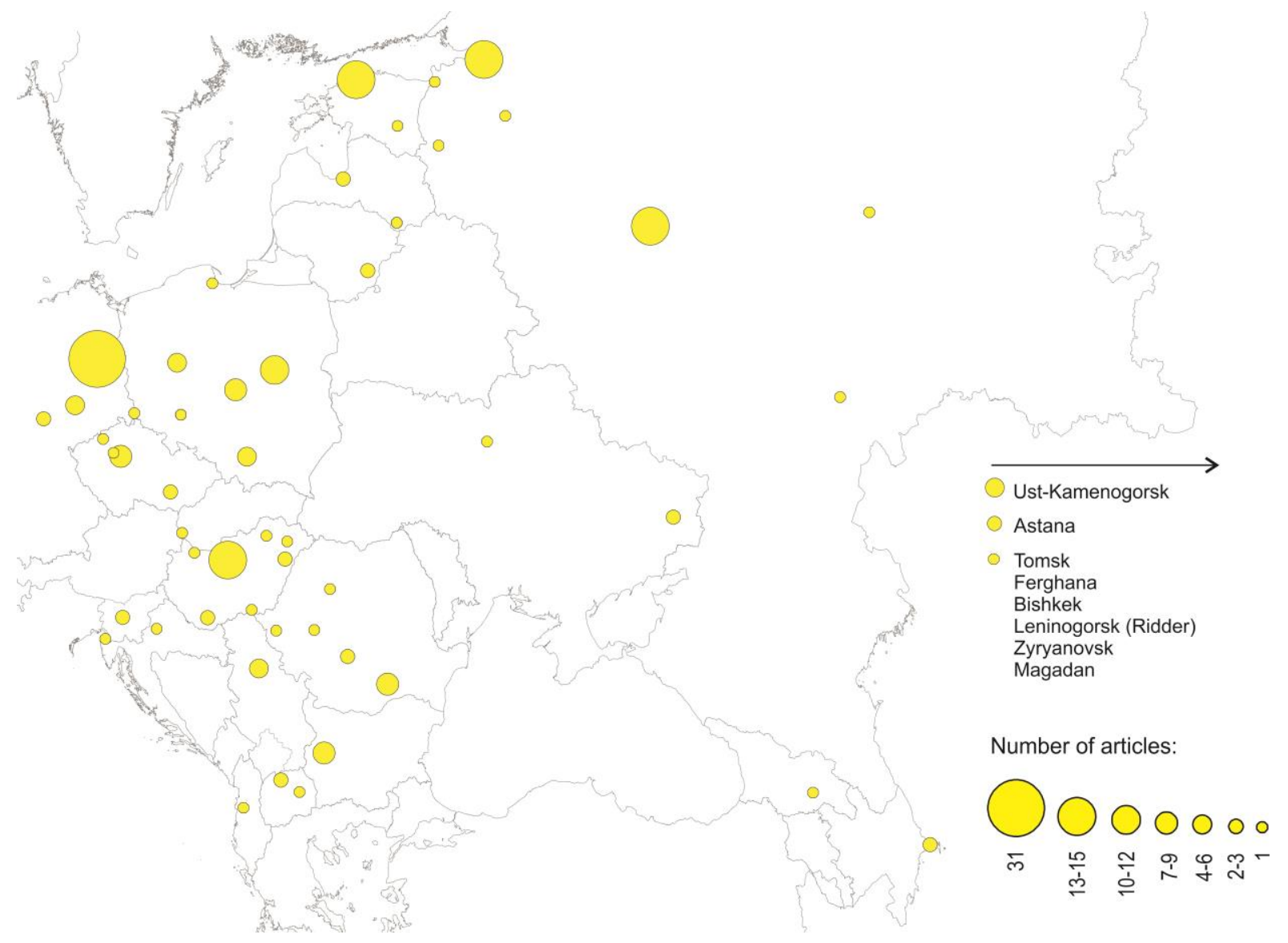




\section{Endnotes}

${ }^{1}$ Traditionally, urban research on CEE cities has been labelled "post-socialist". As the theoretical capacity and value of this label are increasingly questioned (Gentile 2018; Müller forthc.) we have chosen an alternative label: post-Wall (i.e., the Berlin one). Although our focus is on research that explores the situation in cities in of the region, by qualifying it as post-Wall we wish to capture the post-socialist condition as one that transcends the boundaries of the ex-communist countries. Put differently, post-Wall Europe is more than post-socialist Europe, indeed more than "the space we used to call 'post-socialist"' (Ilchenko \& Dushkova 2018, p. 5), and it is, arguably, a more durable concept. Furthermore, rather than reproducing obstinate geographical boundaries, it tries to erase them.

${ }^{2}$ Post-Soviet Geography and Economics until 2001.

${ }^{3}$ This is not to suggest that neoliberalism is no longer occasionally taken for granted. Examples drawn from our sample journals include Chelcea and Druţă (2016), Golubchikov (2016), Haase et al. (2016), Schmiz (2016), Voiculescu and Jucu (2016), Bouzarovski et al. (2017) and others. However, the chosen timeframe also implies that we, as authors, reduce the risk of influencing the sample simply by taking an interest in the issue in focus. The fact is that the authors have contributed articles that are included in the sample and have served as guest editor and editor, respectively, influencing the selection and editing of contributions included in the journals covered here.

${ }^{4}$ Theory is here taken to be "a set of statements that organize a set of hypotheses and relate them to segregated observations." If found to be "valid, it 'explains' and in other words 'consolidates' and federates empirical regularities which on their side would appear segregated" (all in the words of Boudon 1991, p. 520); it is a construct addressing the question "why?".

${ }^{5}$ This policy has since changed, starting with a new editor-in-chief in 2015. 